$$
\begin{aligned}
& 5593 \\
& D 2
\end{aligned}
$$



A COMPARATIVE STUDY OF THE EFFECT OF CUMARIN AND VANILLIN ON - WHEAT GROWN IN SOIL, SAND, AND WATER CULTURES

\author{
A THESIS
}

Presented to the Faculty of the Graduate School OF CORNELl UNIVERSITY FOR THE DEGREE OF DOCTOR OF PHILOSOPHY

\author{
BY \\ JEHIEL DAVIDSON
}

Reprinted from Journal of the American Society of Agronomy, Vol, 7, Nos. 2 and 3. July-August and September-October, 1915. 



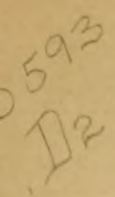

s. 
In exchange

Cornell Univ. Library

NOV 241915

$\because \vdots \vdots$ 


\title{
A COMPARATIVE STUDY OF THE EFFECT OF CUMARIN AND VANILLIN ON WHEAT GROWN IN SOIL, SAND, AND WATER CULTURES. ${ }^{1}$
}

\author{
Jehiel Davidson,
}

Cornell University, IthacA, N. Y.

(Contribution from the Department of Soil Technology, Cornell University.)

The Present Status of the Theory of Soll Toxicity.

\section{INTRODUCTION.}

The theory of soil toxicity dates from the time of De Candolle. Believing that the experiments of Macaire, ${ }^{2}$ which were carried out at his suggestion, proved that plant roots secrete under normal conditions certain organic substances, which in the case of the bean were found to be harmful to the plant that produced them but beneficial to other plants, De Candolle came to consider these root secretions of universal significance in practical agriculture. He proposed to explain the necessity for crop rotation as based on the fact that plants excrete through their roots certain substances that are deleterious to

${ }^{1}$ A thesis submitted to the faculty of the Graduate School of Cornell University in partial fulfillment of the requirements for the degree of Doctor of Philosophy by Jehiel Davidson, B. Sc. Ithaca, N. Y., June, 1914. Received for publication March 30, I9I5.

${ }^{2}$ Macaire, Memoire pour Servir a L'Histoire des Assolemens, Ann. de Chim. et Phys., 52 ( 1833 ), p. 225-240. De Candolle, A. P., Physiologie Vegetale. p. 248-25I. Paris, 1832 . 
the same plants or their near relatives, but which are beneficial to other plants more or less distantly related to them. ${ }^{3}$

Liebig ${ }^{4}$ considered De Candolle's theory of crop rotations " as resting on a firm basis" and placed full reliance in the experiments of Macaire. Although he interpreted the views of both of them in the light of his favorite plant-food theory, he considered the conversion of the injurious excrements of plants into humus as a matter of great importance to soil fertility.

The experiments of Macaire which constituted the principal evidence in favor of harmful root secretions, as well as of root secretions in general, were proved to be erroneous by Braconnot ${ }^{5}$ and others, and De Candolle's views lost their adherents and were forgotten under the dominance of Liebig's mineral theory.

The theory of soil toxicity has been brought to the front again by the Federal Bureau of Soils. It has been modified and broadened. Harmful root excretions and toxic organic substances in general account, according to their views, not only for the inability of a soil to grow the same crop successively for a number of years, but also for the infertility of poor soils in general. They oppose the theory of soil toxicity to Liebig's mineral theory, which in its principal features still has a hold on the minds of the majority of agricultural investigators. To these investigators, plant food, whether of mineral or of organic origin, whether produced by physical, chemical or biological agencies, whether found in the soil originally or introduced in the form of manures and fertilizers, is still the principal key to soil fertility.

Character of the Evidence in Favor of the Theory of Soll Toxicity.

The investigators in the Bureau of Soils have brought forward a considerable amount of evidence in support of their views. The evidence may be divided in two groups. One follows the trail of De Candolle and deals with root secretions, the other deals with the presence in the soil of toxic organic substances in general. It is all, however, of indirect nature and, like all indirect evidence, it holds good only so long as the phenomena on which it is based can be explained only by the theory which it supports.

${ }^{3}$ De Candolle, 1. c., pp. I474-75 and pp. I493-I520.

${ }^{4}$ Liebig, Justus, Chemistry in its Application to Agriculture and Physiology, p. 163-174. Cambridge, 1842.

${ }_{5}^{5}$ Braconnot, H., Recherches sur l'Influence des Plantes sur le Sol, Ann. de Chim. et Phys., 62 (I839), p. 27-40. 
Any other explanation which could be offered to account for the phenomena that serve as evidence in favor of the theory of soil toxicity would rob the evidence of its principal force and relegate the theory in question to a mere hypothesis, more or less plausible. It remains to be seen whether the evidence brought forward stands the criterion of indirect evidence, that is, whether the phenomena on which it is based can not be explained in any way except by the theory of soil toxicity.

\section{Crop Rotations.}

No new evidence has been brought forward since the time of De Candolle to substantiate the view that the failure to grow one crop successfully year after year is due to autotoxic substances secreted by the plant roots. The experiments of Macaire which formed the principal basis of De Candolle's theory, as stated above, have been found to be entirely erroneous. The experiments at Rothamsted ${ }^{6}$ where wheat was grown successfully for fifty years in succession would tend to serve as evidence against the secretion of autotoxic substances by the roots. Up to the present time no root secretions except carbon dioxide have been definitely established.

Passing from facts to general considerations, we can easily come to the conclusion that autotoxic excreta in plants are inconsistent with the general laws of adaptation. We could conceive of excreta which are harmful to other plants as a weapon in the struggle for survival, as was suggested by Humboldt and Plenk ${ }^{7}$ with reference to the existence of plant associations. It is hard, however, to conceive how an autotoxic excretion helped the plants possessing it to survive in the struggle for existence or at least how it did not interfere with them in this struggle.

As to the explanation of the beneficial effects of crop rotations, there are a great number of other factors besides autotoxic secreta which may account for them. These include the different methods of cultivation associated with the different crops in the rotations, the different methods of feeding, the difference in the microbiological flora which accompanies the different crops, etc.

\section{EFfect of Grass on Trees.}

It has been observed on the Woburn Experimental Fruit Farm that grass was injurious to fruit trees. The effect of the grass was so

${ }^{6}$ Gilbert, J. H., Agricultural Investigations at Rothamsted, U. S. Dept. Agr., Office of Exp. Sta. Bul. 22, p. I46-I 7 r.

7 De Candolle, 1. c., p. $1474-76$. 
singular in its character that, according to the authors of the reports, every tree which was grassed over could be easily recognized even if the surface soil were entirely hidden from view.

"The coloring matters in the leaves, bark and fruit are affected in a manner which is not produced by any other form of ill treatment. The bark is pale and much yellower than in a healthy tree; the buds burst at a comparatively early date; and the foliage always exhibits a pale sickly hue, which is quite different from that of trees in the open ground. The autumn tints appear some two weeks earlier than in healthy trees. The fruit, when there is any, shows similar peculiarities of coloring; in case of green apples, for instance, the color is changed either to waxy yellow or to brilliant red."'s

The ill effects of the grass were shown with reference to old trees as well as to newly planted trees. The effects on the latter were in many cases fatal, leading to death after the first season.

The possible reasons for the ill effects of the grass that suggested themselves were deficiency in moisture due to excessive loss of water caused by transpiration from the grass, deficiency in plant nutrients due to competition of the grass, lack of aeration, excessive amounts of carbon dioxide due to respiration of the grass roots, and differences in temperature. The authors of the reports of the Woburn Fruit Farm checked up the influence of every one of these factors and found that none of them could be considered responsible for the characteristic ill effects on the trees produced by the grass. They therefore reached the conclusion that the effect of the grass was due to some direct poisonous action produced by the grass, either through the agency of micro-organisms for the development of which it offers favorable conditions, or directly by secreting some poisonous substance through the roots.

On a closer examination, however, of the methods used in the experiments which were carried out with the object of checking up the individual influences of the factors mentioned above, we find that they were not thorough enough to justify the negative attitude of the experimenters toward these factors with reference to their instrumentality in the ill effects caused by the grass on the apple trees.

To check up the influence of the moisture factor, the experimenters supplied water artificially to the grassed-over trees and found no improvement. They grew trees in closed pots with a supply of moisture limited to such an extent the trees showed signs of actual suffering from thirst, but the peculiar grass effects could not be observed, although the vigor of the trees was markedly impaired. They could

8 Pickering, S. P., The Effects of Grass on Apple Trees, Jour. Royal Agr. Soc. of England, 64 (1903), p. 373. 
not olserve any difference in the alpearance of the grasecel-ower trees between dry and wet seatsons. The grassed-ower trees never showed any indication of actual suffering from thirst."

Is the soil on the experimental farm wats shatlow, there is at puention how moch and for how long the artificial applications of water which were mate weekly and the rains of the wet searone increatect the actual moisture content of the soil. There is alos donth as to how much of the increase was leit at the disposal of the trees, takinge in consideration the fact that grats is steh a poweriul competitur ion moisture. That the trees in the elosed pots did not show the dharacteristic peculiarities of the grassed-ower trees might he due tor the fact that the trees in the foots showed actual signs of sulfering from thirst, while the water supply of the eratsed-oner trees was not deficient to that extent. Would it not have been more direct to have grown trees in pots together with grass and to have hat the monsure properly controlled by weighings at regular intervals?

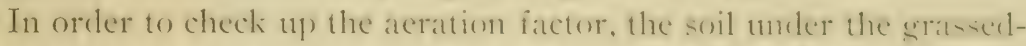
over trees was acrated in various ways and the soil muler trees grown without grass was prevented from leeing acrated as effectively as pussible. No change was observerl by the experimenters in the hehatrion of the trees under either treatment.

However, no mention is made of. how effective the artificial aeration prosed to be, that is, whether or not the soil air wats actmally enriched in oxygen. It further remains questionable whether the grass again diel not prove to be a more puwerful competitor for the increase in oxygen, if any. With reference to the experiments in which acration wats prevented, it is possible that in the absence of ans competition, the exyegen supplied in the water which came from aterated soureses might have been sufficient to stuply the needs of the erees.

The plant-food factor was checked up by growing a two-year-old tree in washed sand which contained very insignificant annomes of the nutrient elements. The tree made good nomal growth for a whole year and survived during the second season withone showing any of the chatateristic grats effects. The experimenters conchuled that the deficiency in plant ford is not the factor which is respumbihle

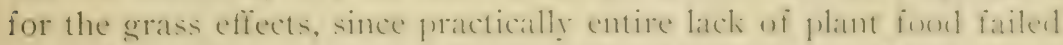
to produce effects similar to those produced by the grass. ${ }^{10}$

There is some question, however, whether there was an entire lack of plant fookl. It is possible that the amount of plant fend contatined in the water with which the tree wals supplied wats -ufficicme we support

э Pickering, S. P., 1. i.

${ }_{10}$ Pickering, S. P., 1. i. 
the normal growth of a two-year-old tree for one season. It is further possible that the deficiency in total plant food is less injurious than the deficiency in one element of plant food, which might have been the case of the grassed-over trees. Would it not have been more to the point, as in the case of the moisture experiment, to have grown the two-year-old tree together with grass in the presence of an abundant supply of balanced plant food?

The principal fallacy of the experiments, however, lies in the fact that the experimenters were trying to obtain the peculiar grass effects from cach of the factors singly, while these effects might have been the result of certain combinations of these factors. The peculiar grass effects as they are described by the Woburn investigators could have been ascribed with a great degree of platsibility to the combined influence of a deficiency in moisture and nitrates. This possibility is strengthened by the fact that when the soil around the trees was planted to clover, the color effects were missing.

The inalility of oak trees to advance into the socalled "oak openings" (grassy tracts) which were found in the natural oak forests of Ohio and Indiana ${ }^{11}$ and the antagonisms existing between butternut trees and shrulbly cinquefoil, reported by Jones and Morse, ${ }^{12}$ as well as the antagonism between peach trees and several grasses reported by Hedrick, ${ }^{13}$ are phenomena similar to those observed on the Woburn Fruit Farm. Toxic excreta or poisonous action in general is not the only possibility which may be offered in their explanation.

\section{Wheat Grown in Association with Tree Seedlings.}

Cierninated wheat seedlings were grown by $\mathrm{C}$. A. Jenseri ${ }^{-*}$ in paraffined pots in association with seedlings of pine, maple, dogwood and cherry. The same number of wheat seedlings were planted in every pot. Successive crops of wheat were grown one after another for periods of two to three weeks. One of the pine seedlings died during the first crop of wheat but the pot was not discarded and received the same treatment as the other pots. Table I (taken intact from Bureau of Soils Bulletin No. 40) gives the relative green weights of the wheat crops.

11 Schreiner, Oswald, and Reed, Howard S., Some Factors Influencing Soil Fertility, U. S. Dept. Agr., Bur. Soils Bul. No. 40, p. 37. 1907.

12 Jones, L. R., and Morse, W. J., Ann. Rep. Vt. Agr. Expt. Sta. I6 (1903), p. I73-I90. U. S. Dept. Agr., Bur. Soils Bul. No. 40, p. I7.

${ }_{13}$ Hedrick, U. P. Proc. Soc. Hort. Sci., 1905, p. 72-82. U. S. Dept. Agr., 13ur. Soils Bul. No. 40, p. I7.

11 Schreiner, Oswald, and Reed, Howard S., 1. c., p. I8-19. 
TABLE I.-Relative Green Wheights of Wheat Crops Growen in Association With Trec Secdlings.

\begin{tabular}{|c|c|c|c|c|c|c|c|c|c|c|c|}
\hline Date of Harvesting. & $\begin{array}{c}\text { June } \\
29 .\end{array}$ & $\begin{array}{l}\text { July } \\
\text { I2. }\end{array}$ & Aug. & $\begin{array}{c}\text { Aug. } \\
22 .\end{array}$ & $\begin{array}{c}\text { Sept. } \\
\text { G. }\end{array}$ & $\begin{array}{l}\text { Oct. } \\
x_{3} .\end{array}$ & $\begin{array}{l}\text { Oct. } \\
29 .\end{array}$ & $\begin{array}{c}\text { Nov. } \\
19 .\end{array}$ & $\begin{array}{l}\text { Dec. } \\
6 .\end{array}$ & $\begin{array}{l}\text { Ave. First } \\
\text { Six Crops. }\end{array}$ & $\begin{array}{l}\text { Ave. Last } \\
\text { Three } \\
\text { Crops. }\end{array}$ \\
\hline Control. . . . . . . & 100 & 100 & 100 & 100 & 100 & 100 & 100 & 100 & 100 & 100 & 100 \\
\hline Maple $1 . . . . . . .$. & 76 & 65 & 86 & 68 & 67 & 86 & 92 & 91 & $x^{6}$ & 74 & 93 \\
\hline$" 2 \ldots \ldots \ldots$ & 44 & 86 & 75 & 59 & 71 & 79 & 90 & 75 & 109 & 71 & $9 \mathrm{r}$ \\
\hline$" \quad 3 \ldots \ldots \ldots$ & $2 \mathrm{I}$ & 83 & 72 & 72 & 79 & 84 & $8 \mathrm{I}$ & 103 & 92 & 70 & 92 \\
\hline Dogwood $x \ldots$. & 92 & 96 & 76 & 84 & 71 & 65 & 85 & 68 & II 5 & $8 \mathrm{x}$ & 89 \\
\hline " $2 \ldots$ & 86 & 79 & 63 & 86 & 75 & 73 & 8.4 & 107 & 88 & 78 & 93 \\
\hline Cherry:.......... & $8 \mathrm{I}$ & $9 \mathrm{I}$ & 102 & 9I & $7 \mathrm{I}$ & 9.4 & 88 & 102 & 93 & 88 & 94 \\
\hline Tulip........... & $2 I$ & 106 & 62 & 77 & 68 & 100 & 77 & 109 & 103 & 75 & 96 \\
\hline Pine.......... & 55 & 69 & 68 & $5^{2}$ & 54 & 80 & 62 & 83 & 60 & 63 & 68 \\
\hline Pine (dead)...... & 62 & 96 & 85 & $9 \mathrm{I}$ & 80 & 89 & 97 & 96 & 67 & 84 & 87 \\
\hline
\end{tabular}

Table I shows that the wheat crops suffered fro:n ansciation with the tree seedlings. The depressing effects of the tree sectlings decreased toward atutum, howerer, as is noticealle especially when the last two columns are compared.

The authors of Bureau of Soils Bulletin No. fo believe that the depressing effects of the tree seetlings were due to toxic excreta protduced by their roots. They believe that this view is horne out by the entire behavior of the experiment. The increase of the relative yichls toward attumn concides with the period when the trees enter upon their seatsonal rest and was due, according to them, to the fact that the toxic excreta were diminished, together with the decrease of the general physiological activity of the deciduous trees. The increated in the yield of the wheat crops grown in association with dogwood was less becanse it was the last to shed its leaves. The pot containing the living pine tree dich not show any increase in the last three cropls. The pot containing the deat pine gare better yields than the other tree pots but inferior to those of the controls. The authors argue that the depressing effects of the trees could not be due to depletion of plant food since "if the trees had remosed sufficient plant fool to starve the wheat plants in the summer period, the increased gichl toward autumn would be incapable of explanation."

Ilowever, the figures presented in the talble do not show any aheolute increase in yielel for the tree pots toward antumn. They only show that they were nearer to the yield of the controls. It is possible that the better crops of the controls had remored towarel the emol of the stmmer nearly as much plant ford as the wheat cropes togecther with the trees in the other pots and this is why there wats len difletence in the respective yedes. Supposing that the yields actually increased toward antumin, the pusibility that the depresting efled of 
the trees was a plant food phenomenon is not at all excluded. The status of avilialle plant food in the soil is dynamic in character. Tlant food is continually heing manufactured in the soil. The same decrease in the plysiological activity of the trees during the period of rest which, according to the authors, catised a decrease in root excreta, also cattsed a decrease in plant food assimilation, and the increased viekl of wheat in the tree pots might have been due to the lessened competition of the trees for plant food.

\section{FAiry Rings.}

This fanciful name is given to rings of grass in pastures or meatows which are markedly darker in color and more luxuriant in growth. In close proximity to the rings, on the outside, various fungi are always found, so that there are really two rings, a ring of grass and a ring of fungi. The diameter of the concentric rings increases crery year and it is generally assumed that the smallest ring is preceded by a single point or by a small continuous area.

Schreiner and Reed ${ }^{15}$ are evidently inclined to interpret this phenomenon in the sense of De Candolle's theory which Way $^{16}$ considers. "by far the most scientific and most intelligent solution of the question," but which he does not accept. The phenomenon of the fairy rings would just fit in De Candolle's theory. The fungi recede because they excrete certain substances which are harmful to themselves but which are beneficial to grass. The excreta beneficial to the grass do not extend very far and therefore the luxuriant growth of grass follows thie fungi in the form of an inner concentric ring.

Way ignores the fact that the fungi do not grow inside of the ring and tries to explain the luxuriant growth of the grass. The fungi, according to Way, are good collectors of the mineral plant food elements. When they die they fertilize the soil in the immediate vicinity and so cause the luxuriant growth of grass of the ring.

The authors of Bulletin No. 40 do not concern themselves with the gratsis, but with the fact that the fungi do not grow inside of the ring. This fact serves, according to them, as evidence in favor of autotoxic plant excreta. The failure of the fungi to grow inside of the ring can not, they say, be due to depletion in plant food, since the analysis of the soil inside and ontside of the rings by Lawes and Gilbert showed too slight differences. Inside of the ring the percentage of nitrogen was 0.247 and of carbon, 2.78 ; outside of the

1. I.. C., I. 37.

1" Way, J. T., On the Fairy Rings of Pastures, etc., Jour. Royal Agr. Soc., 7 (1846), pP. 549-552. 
ring the pereentage of nitrogen was o. 2 ti and of carturne 3.30. The amounts of earbon and nitrogen, howerer, are comsinently higher mnlside of the ring than inside. It is pessilile that the difference is limited to the arailathle organic materials on which fungi grow and. - mall as it is, it may be a factor which determines the growth wi the inngi.

(iillereti interpreted the behavior of the grass and the fungi in the fairy rings entirely in the sense of the plant-food theory.

There is another objection to the use of fairy rings ais criflente in favor of atutotoxic flant excreta. We are hardly jutified in dratwing an analogy between heterotmphic and antotopphic flatnta as we do know for certain that the heterotrophic plants do excrete certain organic substances such as enzymes, and that these sulfolinces are of vital significance in the economy of their nutrition. On the wher hand, we do not know of any secretions by roots of autotrophic plants except carbon dioxid.

\section{The Diminished Yieid of Succeening Crops.}

I number of experinents with wheat in parafined frots were contducted ${ }^{1 s}$ to show that the diminished yield of succeeding crops is the not to depletion of plant food hut w toxic excreta profuced hy the previous crop. The crops were grown for periods of three or four weeks. The results show invarially that the strceeding cropls were considerably lower than the first crops. They funther show that the addition of fertilizers did not change to any considerable extem the proportional relations between the first and the succesling orophe and that the addition of cowpeas and lime was more effective than the addition of mineral fertilizers.

Since young crops could not have removed sufficient plant food to account for the matked decline of the streceeling crop and since the addition of cowpeas and lime which de not fumish immediate flant food proved to be more effective than the achlition of direct plant food in the form of fertilizers, the authors conclute that the depressive effect of the previous crop was due to toxic excreta. In further evidence in this comnection, they consider the fact that, as shown hy their experiments, the mere germination of seeds in a soil i alreatly

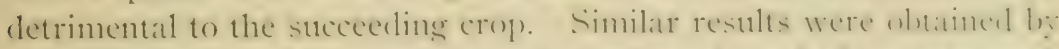

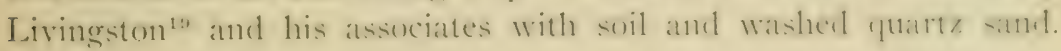
${ }_{17}$ Gilbert, J. H., Note on the Occurrence of Fairy Rings, Jour. of Linnean Soc., I5 (1877), P1. I7-24.

1s Schreiner and Reed. 1. C., P. IO-I5.

10 Livingston, Burton Edward, Britton, J. C., and Reid, R. R., Studies on the Properties of an Unproductive Soil, U. S. Dept. Agr., Bur. Soils Bul. No. 28. 1905. 
The authors of this bulletin do not make it clear whether they consirler the evidence brought forward in this connection as sulstantiating the "toxic" interpretation of crop rotations, that is, whether they would expect different results if several crops were used in a rotation under the same conditions.

The results of these experiments would really tend to show that the depressing effects of the previons crops were not due to depletion of plant food. They do not show conclusively, however, that the inferior yiclds were due to toxic root excreta nor that the secretion of toxic substances might he a factor under natural field conditions. The experiments were conducted under such unnatural conditions that in many of them the depressing effects might have been due to physical deterioration of the soil. This interpretation would he in harmony with the fact that lime and cowpeas had a more decided ameliorating effect than fertilizers.

It is, however, possible that in all the results here reported the depressing effects were due to conditions associated with seed germination, since the crops in all cases were grown only for short periods.

The phenomena of seed germination are so entirely different from condlitions of plant growth after the plant begins to draw its nutrition from the surrounding medium that they ought to be considered separately. The metabolic changes, both destructive and constructive. during the period of seed germination are so rapid, so many different enzymes are involved in the transformation of the products stored up in the seeds, and so much organic material is made available for the growing embryo that the products of seed germination may become harmful to plants when they accumulate, either directly or through the agency of micro-organisms which they may attract.

However, the phenomena associated with the processes of seed gemination are a natural stage in the evolution of plants. Each step in the development of the plant is adlapted to the corresponding stages of the seed metaloolism and its normal growth is, therefore, not interfered with by the products of germination of its mother seed under natural conditions. As to the effect on the succeeding crop, the products of metalolism in the process of seed germination are of such mustable nature that they can hardly be expected to last until the next normal crop and can hardly be a factor in soil fertility under normal conditions when crops are grown to maturity. 


\section{Wheat Seentings Grow: ix Agar. ${ }^{20}$}

Segnents of glass tubing abum three centimeters long and having an internal diameter of 6 to s millimeters were fastened in a vertical position to at glass roxl at intervals of 240.3 millimeters. The segmented tubes were placed in small jars and melted agar wats poured in them till its level reached the surface of the mples -egment. When

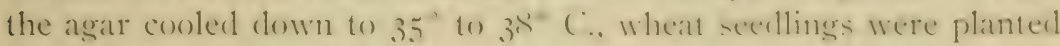
in the tupper segments of the segmented tubes.

- Whout 53 percent of the seedlings grew ont through the openinge of the segmented tules into the strromending agat. When the expertments were repeated with agar in which seedlings hat leen previously allowed to grow at smaller pereentage of the roots curved into the segmented openings. When the same experinnents were carried out in such a way as to eliminate the geotropic tendency of the ronts by the use of a lilinostat, a greater pereentage of roots curved ont into the openings. When fresh agar was used inside of the segnented tules and agar in which seedlings had previonsly been grown ontsicle of them, the percentage of curvatures was smatler. On the other hamel. a larger percentage of curvatures was obtained when used agar was placed inside of the segmented tubes and fresh agar outside of them. Certain relationships were ohtained with reference to the behavior of

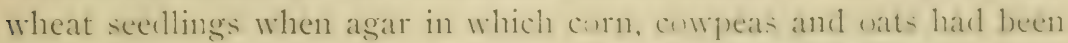
grown was used outside and inside of the segmented tubes.

These facts tend to show, according to the authors, that the routs of the plants included in the experinent exerete ceatain substance deleterious to themselves, but less or not at all deleterions to other plants, the tendency to grow into the openings being atue to the stimuIns of negative chemotropism, a tendency to grow awaly from a harmful substance.

I closer examination of the figures presented in connection with these experiments shows so much rariation between the individual experiments that we are hardly justified in considering the arerages as the expression of the general tendency of the phenomena.

The curving into the openings might have heen due to a canse of a physical nature, the slight tentency of the arerages to hehare in the expected direction heing simply accidental. The growing tip as it is generally known, exerts a considerable pressure. This perhaps forced the agar in the narrow segments into the openings and the roots were carried along with the agar, or the curving inte the ofrenings might have been dae to the general sprealing hathis of the rent system.

20 Schreiner and Reed, 1. c., p. 23-36. 
If, however, the curving into the openings was really due to differences between the agar in the segmenterl tubes and the ontside agar, the theory of toxic excreta is not the only possible explanation. The tendency to curve into the openings might have, been due to water relations, there being more available water outside of the narrow segmented tulse. This possibility becomes more plausible when we take into consideration the fact that while chemotropism in higher plants has not been definitely established, hydrotropism, or the movement toward water, is a well-known phenomenon. ${ }^{21}$

\section{Bemavior of Wheat Seedlings in Water Extracts of Soll. ${ }^{22}$}

The behavior of soil extracts is brought forward as evidence in favor of the existence of toxic substances in soils, regardless of their origin.

It was found that a poor soil extract yields poorer crops than distilled water. The depressing effects of the extract could not be due to lack of plant food, since it contains more of it than the distilled water. When an extract of a poor soil is diluted the yield is improved, notwithstanding the fact that the diluted extract contains less plant food. A case is reported in which the poor properties of a soil extract were transferred to its distillate, which would tend to indicate the presence of some volatile toxic substances. When a poor soil extract was used in making up a balanced solution the yields obtained were inferior to those which were obtained when the same balanced nutrient solution was made up with distilled water. The addition of sulstances which have no nutritive value at all, as pyrogallol, ferric hydrate and carlon black, improves greatly the crop productivity of the poor soil extract. The beneficial effects of these substances is ascribed to their power of alssorbing the toxic substances present in the extracts.

All these facts would tend to show that there is something in the extracts of the poor soils which interferes with plant growth, although some of these facts do not hear necessarily on the presence of toxic bodies. It was found, for instance, that the addition of solids, as carbon black, ferric hydrate, etc., improves a good soil extract also, ilthough not to so great an extent as it improves a poor soil extract. It is possible that the action of the added solid is absorptive, but the worel soil extract also contains comparatively small amounts of toxic substances and it is, therefore, also improved by the addition of ab-

21 Jost, L., Lectures on Plant Physiology, pp. 484-485. Oxford, I907.

2. U. S. Dept. of Agr., Bureau of Soils Bul. 28, 36, and 40. 
sorbing agents. It is, however, alos persible that the effect of the solid is due to some other cattse, the atetion perhate leeing on line plant rather than on the medium. It is possille, for instance, that the solicls stimulate a response in pllant routs just at gravity focs (geotropism). If so, the difierent extent of the effects of the solid on the poor and good soil extract would he due either to the different properties of the extrats which alfect that respmese lifferently, or to the limits of possible improvement.

As to the effects of dilution on the productive capalcity of the poor soil extract, the results obtained lose much of their force as a proof in favor of the theory of soil toxicity hecatse it hats never been tried on a good soil extrate. It would perhaps be fomm that good soil extracts would also be improved by dilution and it would then le pressible to suggest some other explanation of the heneficial effect of dilution in addition to the one based on the dilution of the toxic sulstance.

The yields in the experiments with soil extracts were generally measured by transpiration, which is not always a reliable indicator of plant growth. The plants were grown only for periods of two to three weeks, under which comdition too much significance can not be attached to differences in yich if they are not striking, at was the case in many of these experiments.

The results oltained with soil extracts in general could hardly be considered as due to the same factors which are operative in the poor soils from which they were prepared moler field conditions. This is because the extrats were prepared in such a different mannet for the natural soil solntion (excess of solvent, shaking, ete.), and since the soil, as it was shown, has such an andionating influence on the poor properties of a lifuid medium, even when present in wery small quantities. ${ }^{23}$

Isolation of Toxic Substaxces from Solls.

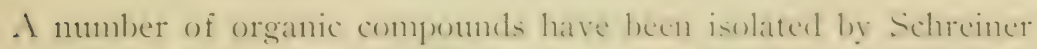
and Shorey" from different soils and some of them have proved to be toxic to plants in water coltures, as picoline carloxylic actil and dihydroxystearic aciel. With reference to picoline carboxylic acill, the anthors have admitted that it was hartly a factor in soil fertility."s: They think, howerer, that dibydroxystearic acid is directly re. sponsible for the poor yielels of the proor soils from which it has heen isolated, since it shows depressing effects in water cultures eren when

23 Livingston, B. E., et al., 1. c., p. 35 .

21 Schreiner, Oswald, and Shorey, Edmund C., The Isolation of Harmful Organic Substances from Soils, U. S. Dept. Agr.. Bur. Soils Bul. No. 53, I 909). 25 L. c., p. 47. 
p)resent in concentrations as low as 20 parts per million. It is questional)le, however, as previously pointed out, whether conclusions with reference to actual field conditions can be drawn from results obtained in water cultures.

Dihychroxytearic acid has been isolated from good soils as well as from pour soils, although much more frequently from the latter than from the former. It has been admitted by Schreiner ${ }^{26}$ that dihydroxystearic acid is perhaps not responsible for the low productive capacity of the poor soils from which it has been isolated and that it is possible that its presence is a result of the same conditions which renter the soils poor. Furthermore, the very presence of dihydroxystearic acid in soils from which it has been isolated is not definitely ('stablished as it is possible that it is formed during the process of extraction.

\section{SuMMARY.}

It is apparent from the foregoing analysis that the evidence which is offered in faror of the theory of soil toxicity is neither direct nor conclusive. The facts on which it is based can be interpreted in a variety of ways other than the existence of toxic substances.

The question would be considered definitely settled if toxic substances isolated from a poor soil, when applied in the same quantity in which they are there present, caused a soil which does not contain them to produce a frow crop similar to that produced by the poor soil.

Indirect or circumstantial evidence is of less value in problems of soil fertility than in many other problems. So many factors known and unknown affect the soil that sereral interpretations of the same phenomena are frepuently possible. The real significance of these thenomena may often escape us becat1se of our lack of knowledge of the processes taking place in the soil.

\section{(To be concluded in the September-October Journal.)}

26 Schreiner, O., and Lathrop, E. C., Dihydroxystearic Acid in Good and Poor Soils, Jour. Amer. Chem. Soc., 33 (I9II), p. I412-I4I7. 


\title{
A COMPARATIVE STUDY OF THE EFFECT OF CUMARIN AND VANILLIN ON WHEAT GROWN IN SOIL, SAND, AND WATER CULTURES.
}

\author{
JEIIEL DAVIDSON, \\ Cornelt University, IthacA, N. Y. \\ (Continued from the July-August number.) \\ Expertatental Data.
}

OHJECT OF TIIE EXPERIMLNTS.

All the laboratory work on soil woxicity dealing with introduced organic deleterions strbiances has been carried out in water cultures. No attempts have ever been mate to detemine how the toxic -uhstances which either have been isolated or which have been thonght possibly to be present in the soil would hehave in actual fich te-t: althomgh it comld reatsmathly be expected that the soil thromgh its many rarions agencies would greatly modify their toxic action."

In the experiments conducted ly the writer during the winter of I912-13, the principal object was to obtain some data as to how sulstances which were found to be toxic to plants in water cultures wonkl atlect cropse grown to matturity in soil, and how these effects would be modified by line, by each individual mineral fertilizer, and by a complete fertilizer. The work was limited to two organic toxins, cunnarin and ranillin. These substances were selected hecante they have been used in a number of experinents with water cultures in order to demonstrate the lehavior of oreanic toxins and heatre they could le easily olfained in sufficient puantitie: in a pure state.

Experiments with water cultures and quartz cultures were conducted parallel with the field experiments.

\section{Experiments witu SOIL.}

The experiments with soil were conducted in 3-sillon prots in the greenhouse. The soil used was Dunkirk clay loam from the ex-

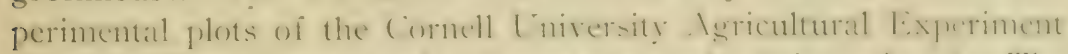
Station. Ten kilegrams of suil were weighed ont in each put. The pots were watered as frepuently as was necestaly, mee a weck at the beginning of the experiment when there wats rery litte transpiration and two to three times at week toward the prerion of maturity.

${ }^{27}$ Since this paper was prepared, a bulletin hy Schreiner and Skinner (Harmful Effects of Aldehydes in Soils, U. S. Dept. Agr. Bul. No. 108, 19r4) has appeared which gives the results of field plat tests with toxic substances. 
()nly distilled water was used. The moisture content of the soil at the time of watering was 30 percent on the dry basis. The pots were liept muler a mulch of white quartz sand. Thirty-six wheat seeds were sown in each pot, the stand afterward being thinned to 12 plants per pot.

The toxins were added in parts per million and were figured on the hasis of the highest total moisture content of the soil at the time of watering. The concentrations used were 200 , I00, and Io parts per million for cumarin, and $\mathrm{I}, 000,500$ and $\mathrm{Io}$ parts per million for vanillin. The highest concentrations used were twice the killing concentrations in water cultures.

The experiments consisted of six series: (I) Without additional treatment, (2) with line, (3) with nitrogen, (4) with phosphoric acid. (5) with potash and (6) with a complete fertilizer. Nitrogen was adrled as sorlium nitrate, phosphoric acid as disodium phosphate, potassium as potassium chloride and lime as calcium hydroxide. Nitrogen, phosphoric acid and lime were added on the basis of 400 pounds per acre, and potassium on the hasis of 200 pounds per acre. Only chemically pure materials were used. Each series consisted of fourteen pots, two for each concentration of the toxins used and two control pots. In the tables which follow, the figures reported are the averages from the duplicate pots in each case.

The toxins, the fertilizers and the lime were added in the dissolved state only. The lime was added as lime water which had been titrated against a standard acid. The addition of toxins was repeated three tinces, each time to the extent of a full equivalent of the total moisture.

\section{Effect on Germination.}

Ahout three weeks after planting, new seedlings ceased to appear alove ground. Before thinning, the seedlings were counted in order to see whether the different treatments had any effect on the germinating power of the seeds. The percentages of germination and the relative germination as compared with the germination in the control pots in each series are given in Table 2.

The only conclusion which would seem to be justified from this table is that none of the different treatments had any effect on germination. The percentages are very irregular, the differences between the duplicates being larger than between the individual treatments. The variations scem to be mere fluctuations and seem to l,e due to sencral conditions affecting germination, as heredity and arencral cnviromusental factors, and not to any single factor arising from a particular treatment. 
TABLE 2.-Effect of Different Concentrations of Cunarin and Vanillin on the Germination of Wheat, as Shozon by the Percentage of Germination and the Ratio of Each to the Control.

\begin{tabular}{|c|c|c|c|c|c|c|c|c|c|c|c|c|c|}
\hline \multirow{2}{*}{ 'Toxin. } & \multirow{2}{*}{ P.p.n. } & \multicolumn{2}{|c|}{$\begin{array}{l}\text { No Treat. } \\
\text { mene. }\end{array}$} & \multicolumn{2}{|c|}{$\mathrm{CaO}$. } & \multicolumn{2}{|r|}{ N. } & \multicolumn{2}{|c|}{$\mathrm{P}_{2} \mathrm{O}_{5}$} & \multicolumn{2}{|c|}{$K_{2}()$. } & \multicolumn{2}{|c|}{$\begin{array}{l}\text { Complete } \\
\text { fiertilizer. }\end{array}$} \\
\hline & & $y$ & К.й. & ten & Rat... & $y$ & Ratio. & \{ & Ratio. & 4 & Ratin. & \& & Katio. \\
\hline Cumarin & 200 & 53 & 76.8 & 67 & 80.7 & 81 & 117.4 & 64 & 79 & 60 & 107.8 & 60 & 88.5 \\
\hline “ & 100 & 64 & 92.8 & 86 & 103.6 & 78 & 113 & $8 I$ & 100 & 67 & 10.9 .7 & 60 & 58.5 \\
\hline “ & IO & 75 & I09 & 75 & 90.4 & 75 & 108.7 & 67 & 82.7 & 69 & 107.8 & 75 & 96.2 \\
\hline Control... & $\ldots \ldots$ & 69 & 100. & 83 & 100 & 69 & 100 & $8 I$ & 100 & 6.4 & 100 & 73 & 100 \\
\hline Vanillin... & I, 000 & 67 & $97 . I$ & 83 & 100 & 69 & 100 & 72 & 88.9 & 75 & 117.2 & 86 & 110.3 \\
\hline . & 500 & $6 \mathrm{I}$ & 88.4 & 83 & 100 & 72 & 104.3 & 72 & 88.9 & 75 & 117.2 & 78 & 100 \\
\hline - & I0 & 75 & 109 & 72 & 86.7 & 67 & $97 \cdot I$ & 78 & 96.3 & 78 & 121.9 & 81 & 103.8 \\
\hline
\end{tabular}

\section{Effect on Yicld.}

The plants in the pots were grown to maturity. Observations taken during the periond of growth diel not lead to any derinte comclusions. It seencel from time to tine that the stand in the cmmarin pots of the two higher concentrations was inferior to that of the control pots in some of the series, espectally in the monictilizel and in the limed series. Ifowerer, 10 almormalities in the appeatrance of the plants in these pots were observed. They looked normally areen and as healthy as the plants in the other pots.

In Talle, 3 the weights of the water-free suhstance for the grain and straw and the total yield are given. The table gives the average weights for the duplicates and the proportional values of the areraeces with reference to the control pots in each series, the yiehl of which are taken as roo.

In the weights of the grain shown in Table 3 there is a certain regularity in the nonfertilized and in the limed series. The highest concentrations give inferor yelds: the lower concentrations give yields either equal to or slightly higher than the combot pots. In the niftrogen series the regularity is preserved with refetence w the cumarin pots, while in the vanillin pots the yields are arranced in the reverse order, the differences, howerer, heing very small. The phosphoric acid series prescrves the regularity exceph for the prot which received the highest concentration of ranillin. These latter gave an abmormally high yidel as compared with the remaining pme of the same series. The fotitsitum series varies very litte ant not in the expected direction. The complete fertilizer series is rory segular. the rariations heing grathal and pronnumeed as in the first two sories.

The weights of the straw are on the whole less regular than those of the grain. The nonfertilizel series follows the regulat mater 
completely. The lined series also varies in the expected direction except in the case of the second concentration of cumarin. The remaining series do not show any regularity in their variations.

TABLE 3.-Weights (Water-free Substance) of Grain, Straw and Total IV cight Obtained from Pot Cultures of Th heat Variously Fertilized and Treated with Different Concentrations of Cumarin and Vanillin, with the Ratio of Each to the Control Taken as ICO.

Weights of Grain.

\begin{tabular}{|c|c|c|c|c|c|c|c|c|c|c|c|c|c|}
\hline \multirow[b]{2}{*}{ 'Toxin. } & \multirow[b]{2}{*}{ P.p.m. } & \multicolumn{2}{|c|}{$\begin{array}{l}\text { No Treat- } \\
\text { ment. }\end{array}$} & \multicolumn{2}{|c|}{$\mathrm{CaO}$. } & \multicolumn{2}{|c|}{ N. } & \multicolumn{2}{|c|}{$\mathrm{I}_{2} \mathrm{O}_{5}$. } & \multicolumn{2}{|c|}{$\mathrm{K}_{2} \mathrm{O}$. } & \multicolumn{2}{|c|}{$\begin{array}{l}\text { Complete } \\
\text { Fertilizer. }\end{array}$} \\
\hline & & 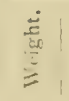 & 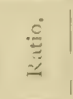 & $\begin{array}{l}\stackrel{\dot{J}}{60} \\
\vdots \\
\vdots\end{array}$ & 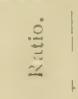 & $\begin{array}{l}\frac{\dot{0}}{\frac{1}{60}} \\
\frac{1}{2}\end{array}$ & $\underset{ت}{\stackrel{0}{ت}}$ & 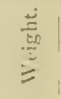 & $\underset{ت}{\stackrel{3}{ت}}$ & $\begin{array}{l}\frac{\vec{\pi}}{80} \\
= \\
=\end{array}$ & $\stackrel{0}{\check{0}}$ & $\begin{array}{l}\frac{\vec{E}}{E} \\
=\end{array}$ & $\stackrel{\circ}{\stackrel{\overbrace{}}{\Xi}}$ \\
\hline Cumarin & 200 & $\begin{array}{l}G m ! \\
4.21\end{array}$ & 64.8 & $\mid \begin{array}{l}\text { Gm. } \\
6.12\end{array}$ & 74.5 & $\begin{array}{l}G m . \\
14.9\end{array}$ & $85 . \mathrm{I}$ & $\begin{array}{l}G m \\
4.96\end{array}$ & So.5 & $\begin{array}{l}\mathrm{Gm} . \\
6.34\end{array}$ & 100.8 & $\begin{array}{l}\text { Gm. } \\
\text { I } 0.9\end{array}$ & 63 \\
\hline , & IOO & 5.08 & $78 . \mathrm{I}$ & 7.55 & 92.0 & 18.3 & 104.6 & 6.42 & 104.2 & 6.61 & 105.1 & 13.8 & 79.8 \\
\hline " & Io & 6.75 & I 03.9 & 7.69 & 93.7 & 18.9 & IOS & 7.16 & I 16.2 & 6.58 & 104.6 & 16.3 & 94.2 \\
\hline Control. & $\ldots 1 \ldots \ldots$ & 6.50 & 100 & $8.2 I$ & 100 & I 7.5 & 100 & 6.16 & 100 & 6.29 & 100 & I $7: 3$ & 100 \\
\hline Vanillin. & . 1,000 & 5.79 & $89 . \mathrm{I}$ & 5.66 & 68.9 & 16.8 & 96 & 9.96 & I6I & 6.93 & 110.2 & 15.2 & 87.9 \\
\hline ". & 500 & 6.72 & 103.4 & 6.48 & 78.9 & 16.3 & $93 . x$ & 6.14 & 99.7 & 6.37 & IOI.3 & I5 & 86.7 \\
\hline " & IO & 7.47 & I I 4.9 & $|8.28|$ & 100.9 & I6.I & 92 & 6.55 & 106.3 & $6.5^{8}$ & 104.6 & I 5.6 & 90.2 \\
\hline
\end{tabular}

WEIGHTS OF STRAW.

\begin{tabular}{|c|c|c|c|c|c|c|c|c|c|c|c|c|c|c|}
\hline Cumarin & & 200 & 23.4 & 85.4 & 25.9 & 92.5 & 54.7 & IO 2 & 25.7 & IOI.6 & 22.4 & I04.7 & 40.0 & 95.2 \\
\hline t" & . & 100 & 25.9 & 94.5 & 29.5 & 105.3 & 55.7 & I03.9 & 27.6 & I00. I & $2 I . I$ & 98.6 & 45.9 & I09. 3 \\
\hline " & & IO & 28 & 102.2 & 27.5 & 98.2 & 53.2 & $99 \cdot 3$ & 27.4 & 108.3 & $24 \cdot 5$ & I I 4.5 & 44.7 & 106 \\
\hline Contr & .. & & 27.4 & IOO & 28 & 100 & 53.6 & 100 & $25 \cdot 3$ & $100^{\circ}$ & $2 \mathrm{I} .4$ & 100 & 42 & 100 \\
\hline nillin & & 1,000 & 24.6 & 89.8 & 22.9 & 81.8 & 48.9 & 91.2 & 34.8 & 137.6 & 24.9 & I I 6.4 & 43.9 & 104.5 \\
\hline & & 500 & 27.1 & 98.9 & 24.7 & 88.2 & 50.3 & 93.8 & 24.2 & 95.6 & 20.3 & 94.9 & 47.5 & II $3 . I$ \\
\hline$\because$ & & IO & 28 & 102.2 & 28.5 & Ior.8 & 52.5 & 97.9 & 23.2 & 91.7 & 19 & 88.8 & 46.4 & I IO. \\
\hline
\end{tabular}

Total Weights.

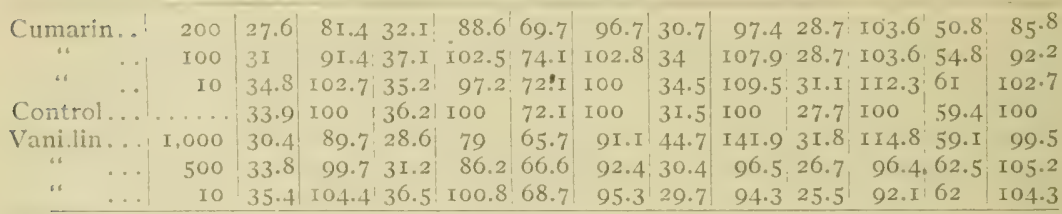

The total yictels of the grain and straw naturally occupy a place between the weights of each separately with reference to the tendency to show a regular trend in any direction. The nonfertilized and the limed series again prove to be the most regular. The com1. Hete fertilizer scries comes next, being (puite regular in the cumarin pots. The nitrogen series shows a tendency to regularity, being more regulat in the vanillin half. The potassium series again proved to be the least regular. On the whole, the variations in the total yield are not very sharp. 
The general inpression proluced by examination of Table 3 wonld he that the highest concentrations of the cumatrin and vanillin caused a slight depresion in yiekl, especially in the yiehl of erain, and that the depression is more pronomecel and more resulat in the nonfertilizerl, in the limesl, and in the complete fertilizer series. The ardition of the individual fertilizers seened to have a disturthing influence on the temfency of follow the regular effects of the wexins 1tsed." No conclusion can le drawn as to whether it was acedental (which is not improbalele in view of the fact that the vartations in general were not very sharp) or whether it was due to the influence of the fertilizer. Seither is it possible to draw any conclusions with reforence to the effects of the indivilual fertilizers in the aldence of distinct variations since there was only one series for eatch fertilizer. The complete fertilizer did not seem to modify the effects of the cumarin and vanillin.

\section{Effect on the Nitrogen Content.}

The nitrogen content may serve sonetines as an inclication of the presence of certain factors which influence the gencral yidul of a

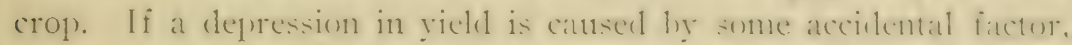
the tendency is in the direction of a relatively higher nitrogen content. The reason for this phenomenom might be doe either wo the fact that the interering factor does not affect the production of mitrates in the soil, or that it does not atfect the assimilative power of the plant for nitrogen. It was thught, therefore, that the nitregen content of the crops might throw some light on the nature of the influenes exerted by the comatrin and vanillin treatment. Table + gives the pereentages of nitrogen in the grain and in the stran and the ratios of the difierent treatments to the control, taking the fercentage of nitrogen in the controls as IOO.

Fxamining these taliles, we find that the percentages of nitrogen in the straw fluctuate too irregularly to allow of any generalizations. We find, for instance, that in the nenfertilized and the lined series. which proved to be the most regular ones with reference to the weight of water-free substance the highest concentrations of cuntarin and vanillin gave approxinately the same fereentages as the controts. In the remaining series, the concentration of 200 parts per million of cumarin gave sonewhat higher perentages than the controls. The other concentrations of cumarin, as well as all the concentrations of vanillin, do not follow any regular order. 
TABLE 4.-Nitrogen Content of Wheat Grain and of Strazo Grown in Pot Cultures Variously Fertilized and Treated with Different Concentrations of Vanillin and Cumarin, with the Ratio of Each to the Control Taken as roo.

Wheat Grain.

\begin{tabular}{|c|c|c|c|c|c|c|c|c|c|c|c|c|c|}
\hline \multirow[b]{2}{*}{ Toxin. } & \multirow[b]{2}{*}{ P.p.m. } & \multicolumn{2}{|c|}{$\begin{array}{l}\text { No Treat- } \\
\text { ment. }\end{array}$} & \multicolumn{2}{|c|}{$\mathrm{CaO}$. } & \multicolumn{2}{|c|}{ N. } & \multicolumn{2}{|c|}{$\mathrm{P}_{2} \mathrm{O}_{5}$. } & \multicolumn{2}{|c|}{$\mathrm{K}_{2} \mathrm{O}$} & \multicolumn{2}{|c|}{$\begin{array}{l}\text { Complete } \\
\text { Fertilizer. }\end{array}$} \\
\hline & & 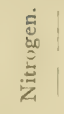 & 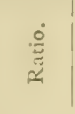 & 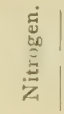 & 芯 & 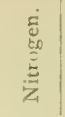 & نُ & 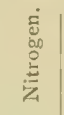 & 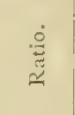 & 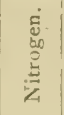 & $\dot{\mathscr{\Xi}}$ & 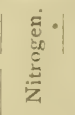 & 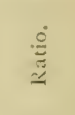 \\
\hline Cumarin & 200 & $\begin{array}{c}\% \\
1.72\end{array}$ & 107.5 & $\begin{array}{c}\% \\
1.9 I\end{array}$ & I07.9 & $\begin{array}{c}\% \\
2.27\end{array}$ & II 3.5 & $\begin{array}{c}\% \\
2.15\end{array}$ & II 4.4 & \begin{tabular}{|c|}
$\%$ \\
2.06
\end{tabular} & 106.7 & $\begin{array}{c}\% \\
2.15\end{array}$ & I08.6 \\
\hline & 100 & I. 75 & 109.4 & I. 76 & 99.4 & $2.0 \mathrm{I}$ & 100.5 & 2.00 & I 06.4 & I. 95 & IOI & 2.09 & 105.5 \\
\hline " & I0 & $\mathrm{I} .8 \mathrm{I}$ & I I 3.1 & I. $5^{8}$ & 89.3 & 2.07 & I03.5 & I.96 & I0 4.3 & I. 89 & 97.9 & 2.10 & 106.1 \\
\hline Control. & & 1.60 & 100 & r. 77 & 100 & 2.00 & 100 & I. 88 & 100 & I.93 & IOn & 1.98 & I00 \\
\hline Vanillin. & $I, 000$ & 1.76 & IIO & 1.89 & I06.8 & I.89 & 94.5 & r.97 & I04.8 & 1.89 & .97 .9 & 2.03 & I02. 5 \\
\hline & 500 & I. 82 & II 3.7 & I.68 & 94.9 & $2.0 \mathrm{I}$ & 100.5 & I. 98 & 105.3 & I.93 & 100 & 2.06 & 104 \\
\hline 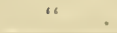 & ro & r.68| & 105 & $\mathrm{I} .8 \mathrm{I}$ & 102.3 & $2.04 !$ & 1027 & I.93 & 102.7 & I.97! & $102 . \mathrm{I}$ & $|2.13|$ & 107.6 \\
\hline
\end{tabular}

Wheat Straw.

\begin{tabular}{|c|c|c|c|c|c|c|c|c|c|c|c|c|c|}
\hline Cumarin & 200 & 0.39 & 102.6 & 0.33 & I03. & 0.46 & I35.3 & 0.45 & II 8.4 & 0.39 & II 4.7 & 0.35 & I 12.9 \\
\hline & 100 & .31 & 81.6 & .34 & 106.2 & $.4 \mathrm{I}$ & I 20.6 & .33 & 86.8 & .32 & 94.I & .35 & I I 2.9 \\
\hline " & Io & $.3 I$ & 81.6 & .38 & II 8.8 & .38 & IIT.S & .34 & 89.5 & .35 & I02.9 & .35 & I 12.9 \\
\hline Control & & .38 & 100 & .32 & 160 & .34 & 100 & .38 & 100 & .34 & 100 & $.3 \mathrm{I}$ & 100 \\
\hline Vanil & 1,000 & .42 & 110.5 & .32 & 100 & .36 & 105.9 & .36 & 94.7 & .30 & 88.2 & .29 & 93.6 \\
\hline & 500 & $.4 \mathrm{I}$ & I07.9 & .30 & 93.7 & .40 & II 7.6 & .36 & 94.7 & .32 & 94.I & .39 & 125.8 \\
\hline . & 10 & .30 & 78.9 & .33 & I03.I & .43 & $\mid 126.5$ & .39 & $|102.6|$ & .37 & $|108.8|$ & .42 & 135.5 \\
\hline
\end{tabular}

The percentages of nitrogen in the grain exhibit a regularly borne out consistency with reference to the concentration of 200 parts per million of cumarin, as they are consistently higher than those of the controls in all the series. With reference to the remaining concentrations of cumarin and those of vanillin, the consistency varies with the series, and does not, on the whole, allow any generalizations as in the case of the straw.

The depression in yield of grain, which was most pronounced in the case of the concentration of 200 parts per million of cumarin, would seem to he accompanied by a relatively higher nitrogen content which is characteristic of the presence of some factor interfering with plant growth. The question is whether the effect of the interfering factor was directly on the plant, causing some morphological derangement or interfering with its physiological functions, or whether the effect was on the medium in which it grew.

The appearance of the plants in the pots to which the toxic substance harl been adrled was perfectly normal, as stated above. The rots were found to permeate the soil in every direction and did not thow any inferior development as compared with the controls. The 
depresion in yicld was not evidently due to lack of nitrogen, but the possiliblity of its being due to a relative deliciency in sme of the other available clements of plant food, actual or phy solugical, canded by the interfering factor, is not excluded. It is also possible that the interfering factor alfected the plosical and hological comblitions of the soil.

\section{Effect on Nitrates.}

In oreler to ohtain some idea of the ellect of the toxins need on the hiological activity of the soil, the soil in the pots was analyzerl for nitrates.

The pots conld not he handled immediately after the croms were harvested, hut were held at a low moisture content and were analyzerl, a complete series at a time, so that each series combl he compared omly. with its own control pots. J)uring the sampling, the soil wats remored from the pots, pulverized, and thoroughly mixerl. Ifter the first sampling. the soil was retumed to the pots, liept at about 25 pereent of moisture for a time, and analyzed again. This was analogous to inculation, as the pots were liept in the greenhonse and were all subject to the same variations in temperature, which (the weather at that time of the year heing constant) were linsiter only to the difference of the day and night temperature. Igain, one series was handled at a time, so that each series was inculated for a different length of time.

The nitrates in parts per million are given in Tables 5 and 6 . In Table 5 the averages of the duplicate pots are comprated with the averages of the control pots in each series, the latter leding taken as Ioo. In Table 6 the increatse in nitrates for the preriod of incubation was calculated and the arerage increase of the duplicate pots is compared with the arerage increase of the control pots taken as ron.

TABLE 5.-Nitrates in Pot Cultures Variously Fertilized and Treated with Different Concentrations of Cumarin and Vanillin, as Determincd before

Incubation, with the Ratio of Each to the Control Taken as 100.

\begin{tabular}{|c|c|c|c|c|c|c|c|c|c|c|c|c|c|}
\hline \multirow[b]{2}{*}{ Toxin. } & \multirow[b]{2}{*}{ P.p.m. } & \multicolumn{2}{|c|}{$\begin{array}{l}\text { No Treat- } \\
\text { ment. }\end{array}$} & \multicolumn{2}{|c|}{$\mathrm{CaO}$. } & \multicolumn{2}{|c|}{ N. } & \multicolumn{2}{|c|}{$\mathrm{P}_{2} \mathrm{O}_{5}$} & \multicolumn{2}{|c|}{$\mathrm{K}_{2} \mathrm{O}$. } & \multicolumn{2}{|c|}{$\begin{array}{l}\text { Complete } \\
\text { Fertilizer. }\end{array}$} \\
\hline & & 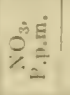 & $\stackrel{\circ}{3}$ & 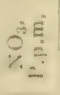 & $\stackrel{0}{2}$ & 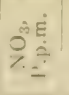 & 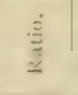 & 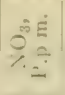 & 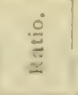 & 它官 & $\stackrel{0}{3}$ & 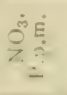 & $\frac{c}{3}$ \\
\hline Cumarin . & 200 & I 5.6 & 82.5 & 33.5 & 97.1 & $20 . I$ & 57.8 & 37.3 & I I 9.2 & 36.6 & 106.1 & 52.2 & 64.3 \\
\hline$"$ & 100 & I 4.2 & $75 . I$ & 31.8 & 92.2 & 22.9 & 65.9 & +4.8 & $\mathrm{I}+3 . \mathrm{I}$ & 36.6 & 100.1 & 52.8 & 05 \\
\hline " & Io & I6 & 84.7 & 32.3 & 93.6 & $3 \pi .6$ & 90.8 & 36.5 & I 16.6 & 36.7 , & 106.4 & $5 x .6$ & $6.3 \cdot 5$ \\
\hline Control... & $\ldots \ldots$ & I 8.9 & I00 & $34 \cdot 5$ & I00 & $34.8:$ & 100 & 31.3 & 100 & 34.5 & 100 & 81.2 & 100 \\
\hline Vanillin.. & 1,000 & 9.4 & 49.7 & 19.8 & 57.4 & 2.3 .2 . & 66.7 & 60.6 & 193.6 & $3 \mathbf{I}$ & $89.0^{\circ}$ & 52.2 & 04.3 \\
\hline & 500 & II. 2 & 59.3 & 24.7 & $71.6^{\prime}$ & $38.3 !$ & I I O ! & 35.0 & I 13.7 & 33.7 & 97.7 & $\$ 3.0$ & 53.7 \\
\hline - & IO & I 5.2 & 80.4 & 26 & 75.4 & 29.9 & 85.9 & 32.5 & 103.8 & .21 .5 & 62.3 & 55.9 & 68.5 \\
\hline
\end{tabular}


TABLE 6.-Increase of Nitrates after Incubation from Pot Cultures Variously

Fertilined and Treated with Different Concentrations of Cumarin and I unillin, with the Katio to the Control Taken as 100.

\begin{tabular}{|c|c|c|c|c|c|c|c|c|c|c|c|c|}
\hline \multirow[b]{2}{*}{ Tovin. } & \multirow[b]{2}{*}{$\mathrm{l}^{\mathrm{p}}, \mathrm{p}, \mathrm{m}$. } & \multicolumn{2}{|c|}{$\begin{array}{l}\text { No 'l'reat- } \\
\text { ment. }\end{array}$} & \multicolumn{2}{|c|}{$\mathrm{CaO}$. } & \multicolumn{2}{|c|}{ N. } & \multicolumn{2}{|c|}{$\mathrm{P}_{2} \mathrm{O}_{\mathrm{s}}$. } & \multicolumn{2}{|c|}{$\mathrm{K}_{2} \mathrm{O}$. } & \multirow{2}{*}{ 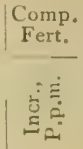 } \\
\hline & & 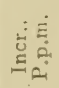 & 芯 & نَّة & 站 & 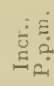 & شِ & 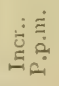 & $\begin{array}{l}\stackrel{8}{\Xi} \\
\text { స్ }\end{array}$ & 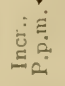 & 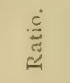 & \\
\hline Cumarin. & 200 & 42.9 & 129.6 & 23.9 & 85.4 & 21.6 & 73 & 29.9 & 198 & I 4.6 & 69.2 & I 7.4 \\
\hline & 100 & 41.7 & 126 & 23.5 & 83.9 & 26.4 & 89.2 & 3 I & 208.3 & 9.5 & 48.1 & 9.9 \\
\hline . & I0 & $34 \cdot 3$ & 103.6 & 27.5 & 98.2 & 33.7 & II 3.8 & 29.7 & I96.7 & $2 \mathrm{I} .5$ & IOI.9 & 16.3 \\
\hline Control. & & 33.1 & 100 & 28 & 100 & 29.6 & 100 & I5. I & 100 & $2 \mathrm{I} . \mathrm{I}$ & 100 & Loss \\
\hline & $\mathrm{I}, 000$ & $24 \cdot 3$ & 73.4 & I9.5 & 69.6 & 31.9 & 107.8 & 27.5 & I 82.I & 14.9 & 70.6 & 14.3 \\
\hline & 500 & 28.2 & 84.6 & I9. I & 68.2 & 22.2 & 75 & 23.4 & I 55 & II .2 & 53.I & I 5.5 \\
\hline & IO & 51.7 & I 56.2 & 24.6 & 87.9 & 26.5 & & 22.9 & I5I.6 & 9.9 & 46.9 & 25.4 \\
\hline
\end{tabular}

As is seen in Table 5, the nitrates in four series are consistently higher in the control pots than in the pots to which the toxins had been arlded. The phosphoric acirl series goes in the opposite direction and the potassium series is only partially consistent.

Table 6 , presenting the data for the incubation period, shows that in the toxin-treated pots of the lime, the nitrogen, and the potassium series the increase in nitrates is lower than in the control pots. The phosphoric acid goes the other way as in the period preceding inculation. In the complete fertilizer series, the control pots showed a reduction in nitrates instead of an increase, so that there is no standard of comparison. In the nonfertilized series, the increase in the control pots was larger than in the vanillin pots, but smaller than in the cumarin pots. This might have been due to the fact that this series was incubated for the longest period of time and the cumarin was completely decomposed. As will be seen later, there are indications that the effects of cumarin are more subject to amendment through decomposition by the soil agencies than are the effects of vanillin.

The general impresion produced by the figures representing the results of the analysis for nitrates, would be that the addition of the toxins used seemed to interfere with nitrification.

The behavior of the cumarin and the vanillin with reference to their effects on nitrification would seem to be analogous to the behavior of soluble organic matter in general. König, Hasenbäumer and Glenk 25 found that the addition of glucose invariably inhibited nitrification. The inhibiting effect of soluble organic matter on

2s Konig, J., Hasenbaumer, J., and Glenk. K., Uber die Anwedung der Dyalise, etc., Landw. Vers. Stat, 79-80 (I9I3), p. 49I-534. 
nitrilication might he cither directly on the nitrifying organt 1 or on

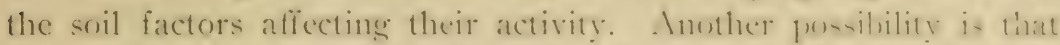
the soluble oreanic matter stimulates the growth of oflect lincteria

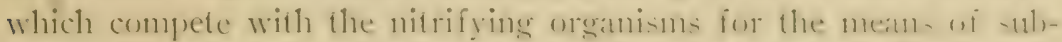

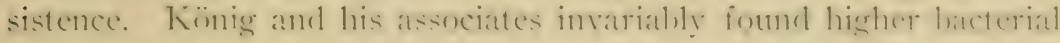
numbers as a result of the addition of glucose.

\section{Effect on Conductivity.}

The same anthors foumd that the addition of glucose rerlueed the conductivity of the soil. The explanation sugesested by them is that the glucose ate protedively tomarel the electrolytes of the wil, thus interfering with the movements of the ions. In discusing the depression in yichl, which under certain conditions is produced les the addition of stugar, the anthors steggest that the electrical comblutisity or the morement of the ions is in itself a factor in soil fertility. It was, therefore, interesting to see how the cumarin and vanillin, which produced a slight depression in vicld practically similar to that produced by the addition of glueose, wothle affect the comblutivity of the soil in the experimental pots.

Fifty grams of soil were thoroughly mixed with 50 percent of distilled water on the dry hasis, and the resistanee measured hy a Wheatstone bridge. Tables 7 and 8 show the resistance in whms calculated at $60^{\circ} \mathrm{F}$. before and after incubation.

The results are not entirely consistent, hut nevertheless a seneral inspection of the talles gives the inpression that the suil in the prots to which cumbrin and ranilin had been adted showed a smewhat higher conductivity as compared with the control pots, for the preriod following incubation.

TABLE 7.-Effect on Conductivity of Various Fortiliners and Treatments acith Different Concentrations of Cumarin and Vanillin, as Shown by the Resistance in Ohms Calculated at $60^{\circ} \mathrm{F}$. before Incubation, with the Ratio of Each to the Control.

\begin{tabular}{|c|c|c|c|c|c|c|c|c|c|c|c|c|c|}
\hline \multirow{2}{*}{ Toxin. } & \multirow{2}{*}{ E் } & \multicolumn{2}{|c|}{$\begin{array}{l}\text { No Treat- } \\
\text { ment. }\end{array}$} & \multicolumn{2}{|c|}{$\mathrm{CaO}$. } & \multicolumn{2}{|c|}{$\mathrm{N}}$. & \multicolumn{2}{|c|}{$\mathrm{P}_{2} \mathrm{O}_{5}$} & \multicolumn{2}{|c|}{$\mathrm{K}_{2} \mathrm{O}$. } & \multicolumn{2}{|c|}{$\begin{array}{l}\text { Complete } \\
\text { Fertilizer. }\end{array}$} \\
\hline & & $\begin{array}{c}\text { Resist. } \\
\text { ance. }\end{array}$ & Ratio. & $\begin{array}{l}\text { Resist- } \\
\text { ance. }\end{array}$ & Ratio. & $\begin{array}{l}\text { Resist- } \\
\text { ance. }\end{array}$ & Ratio. & $\begin{array}{l}\text { Resist- } \\
\text { ance. }\end{array}$ & Ratio. & $\begin{array}{l}\text { Resist- } \\
\text { ance. }\end{array}$ & Ratio. & $\begin{array}{l}\text { Resist- } \\
\text { ance. }\end{array}$ & Katio. \\
\hline Cumarin & 200 & 174 & & & 96.7 & & I 12.7 & 1.779 & 82.3 & 1,609 & I 15.2 & 1.774 & 99.7 \\
\hline & 100 & .229 & 106.8 & 2,003 & 99.6 & 2,250 & $1 \mathrm{I} 8.7$ & 1,720 & 79.6 & 1,700 & 121.7 & $1,08 \mathrm{I}$ & 94.5 \\
\hline " & ro & 2.369 & I 13.5 & $2,18 \mathrm{I}$ & 107.1 & 1.996 & 105.3 & I.95I & 90.3 & 1,701 & 121.8 & 1,702 & 95.7 \\
\hline Control & $\ldots \ldots$ & 2,087 & 100 & 2,038 & 100 & 1,896 & 100 & $2,16 \mathrm{I}$ & 100 & 1,397 & 100 & 1,770 & 100 \\
\hline Vanillin & $1.10 \times 1$ & $2 \ldots+16$ & 11.5 .8 & 2.32 .1 & Tr! & $1.9 \div 5$ & 28.0 & I.7II & 70.1 & $1,5,00$ & 113 & I 682 & $n ! 3$ \\
\hline .. & 500 & 2,195 & 105.2 & $2,1 f^{\prime \prime}$ & 126.1 & $1,55^{\circ 1}$ & SI.S & 1.081 & ดा. & $1,3,3$ & $15:$ & 4.714 & yne. i \\
\hline$\because$ & Io. & $|1,970|$ & 94.8 & 2.48 .4 & 121.9 & 1.675 & $|88.3|$ & $\mid 1,95 \mathrm{I}$ & 190.3 & 1.944 & $|1.39 . \mathrm{I}|$ & $|1.423|$ & So \\
\hline
\end{tabular}


TABLE 8-Effect on Conductivity of Various Fertilizers and Treatments with Different Concentrations of Cumarin and Vanillin, as Shown by the Resistance in Ohms after Incubation Calculated at $60^{\circ} \mathrm{F}$., with the Ratio of Each to the Control.

\begin{tabular}{|c|c|c|c|c|c|c|c|c|c|c|c|c|}
\hline \multirow{2}{*}{ Toxin. } & \multirow{2}{*}{$\begin{array}{l}\dot{E} \\
\dot{0} \\
2\end{array}$} & $\begin{array}{l}\text { No Treat- } \\
\text { ment. }\end{array}$ & \multicolumn{2}{|c|}{$\mathrm{CaO}$. } & \multicolumn{2}{|c|}{ N. } & \multicolumn{2}{|c|}{$\mathrm{P}_{2} \mathrm{O}_{5}$} & \multicolumn{2}{|c|}{$\mathrm{K}_{2} \mathrm{O}$. } & \multicolumn{2}{|c|}{$\begin{array}{l}\text { Complete } \\
\text { Fertilizer. }\end{array}$} \\
\hline & & $\begin{array}{l}\text { Resist- } \\
\text { ance. Ratio. }\end{array}$ & $\begin{array}{l}\text { Resist- } \\
\text { ance. }\end{array}$ & Ratio. & $\begin{array}{l}\text { Resist- } \\
\text { ance. }\end{array}$ & Ratio. & $\begin{array}{l}\text { Pesist- } \\
\text { ance. }\end{array}$ & Ratio. & $\begin{array}{l}\text { Resist- } \\
\text { ance. }\end{array}$ & Ratio. & $\begin{array}{l}\text { Resist- } \\
\text { ance, }\end{array}$ & Ratio. \\
\hline Cumarin & 200 & $\mathbf{I}, 68090$ & I, 5 I 5 & 93.2 & I, 550 & I IO & I,499 & 86.8 & I,356 & I02 & $I, 642$ & 103.2 \\
\hline & IOO & $\mathbf{I}, 867 \mathbf{I} 00$ & $\mathrm{I}, 580$ & 97 & $\mathrm{I}, 700$ & 120 & I, 430 & 82.8 & $I, 455$ & I09 & $I, 488$ & 93.5 \\
\hline “ & IO & $\mathrm{I}, 929 \mathrm{IO} 3$ & 1,633 & 105 & $I, 487$ & 105 & 1,653 & 95.7 & $\mathrm{I}, 38 \mathrm{I}$ & I03.8 & $I, 540$ & 96.8 \\
\hline Control & $\ldots \ldots$ & $\mathrm{I}, 867, \mathrm{I} 00$ & 1,625 & 100 & 1,412 & 100 & 727 & 100 & I,330 & IOO & $\mathrm{I}, 59 \mathrm{I}$ & IOO \\
\hline Vanillin & 1,000 & $x, 736 \quad 93$ & $\mathrm{x}, 8 \mathrm{I} 7$ & I I 2 & $\mathrm{I}, 475$ & & $\mathrm{I}, 430$ & 82.8 & 1,307 & 98.3 & $I, 540$ & 96.8 \\
\hline & 500 & $x, 744$ & I, 732 & 107 & $\mathrm{I}, 525$ & 108 & I, 628 & $94 \cdot 3$ & $I, 233$ & 92.7 & $\mathrm{I}, 565$ & 98.4 \\
\hline & IO & $1.649 \quad 88.3$ & I,694 & I04 & I, 600 & $I_{3}$ & $\mathrm{I}, 80 \mathrm{I}$ & 104.3 & $I, 529$ & II 5 & $\mathrm{I}, 283$ & 80.6 \\
\hline
\end{tabular}

This, however, is not directly contradictory to the results obtained by König and his associates, since we have introduced the crop factor, while their results were obtained without growing any crop in the soil experimented with, and since the measurements in these experiments were made a comparatively much longer time after the organic substances were added.

The soil in the cumarin and the vanillin pots seemed to show after incubation a higher conductivity in spite of the fact that the respective treatments apparently reduced their nitrate content. It is possible that the plants withdrew from the soil, in the presence of the toxins used, less of the other electrolytes. This might have been due either to the fact that the toxins interfered directly with the absorption of these electrolytes by the plant, or that they stimulated the growth of microorganisms which held the electrolytes tied up in their tissues at the time of active plant growth.

That organic substances which prove to be toxic to higher plants in water cultures may he favorable to the growth of microorganisms, was shown by the fact that a solution containing 200 parts per million of cumarin showed to the naked eye an abundant growth of molds ancl fungi when allowed to stand for some time. The same was true with dihydroxystearic acid which had been isolated from a soil in Tompkins County, New York.

It is remarkable that König and his associates failed to see the possibility of any connection between the higher bacterial numbers resulting from the addition of sugar and the other phenomena resulting from the same treatment, as depression in yield, lowering of conductivity, and the reduction in the nitrate content. Such a con- 


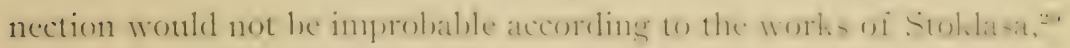
Severin ${ }^{30}$ and Duschetschkin. ${ }^{31}$

\section{Experiments with IVAter Cultures.}

\section{Effect on Germination.}

Wheat seeds were allowed to germinate on filter paprer in petri dishes. Fifty seeds were placed in each dish to which I5 c.c. of solutions of the respective coneentrations of combarin and vanillin were adkled. Fifteen ce, of distilled water were alderl on the control petri dishes. The test was run in duplicate. Observations were taken after six and ten days. Table 9 shows the results obtained after six days.

TABLE 9.-Effect of Different Concentrations of Cumarin and Vanillin on the Germination of Wheat in $I V$ ater Cultures.

\begin{tabular}{|c|c|c|c|c|}
\hline Toxin, & P.p.m. & $\begin{array}{l}\text { Average } \\
\text { Germina- } \\
\text { tion. }\end{array}$ & Percent. & Description of Seedlings. \\
\hline Cumarin.... & 200 & 0 & o & \\
\hline$\cdots$ & 100 & & & \\
\hline " $\quad \ldots$ & IO & 22 & 44 & Normally developed seedlings. \\
\hline Control..... & $\ldots \ldots \ldots$ & 22 & 44 & Better than in the previous case. \\
\hline Vanillin.... & I,000 & 5 & Io & Very weak. \\
\hline$" \quad \ldots \ldots$ & 500 & 9 & I 8 & $\begin{array}{l}\text { Better than in previous case. Some poor } \\
\text { but normal seedlings. }\end{array}$ \\
\hline$\ldots \ldots$ & 10 & 26 & 52 & Vigorous. \\
\hline
\end{tabular}

Most of the seeds which are recorded as not germinated in reality marle slight efforts to germinate, lout evidently the seedlings were killed in the earliest stage of embryonic development.

The second observations did not reveal any changes with reference to the cumarin treatment, execpt that the seeds were all overgromin with molds and fungi. The vanillin petri dishes, howerer, showed consislemale improvement, especially those which received 500 parts per million. In these the perecutage of gemmation and the percentage of normally developed seedlings increased considerably (germination, 32 pereent; normally developed secellings. zf perent)

It is thus seen that cumarin had a more injurious effect on germination than vanillin. It is also seen that the deleterints elled of

29 Stoklasa, Julius, Biochemischer Kreislauf des Plosplat-ions im Boden, Centbl. Bakt., 29, (II), I9II, P. 385-5I9.

30 Severin, S. A., Changes of Phosphoric Acid in the Soil, etc., Centl)1. Bakt., 28, (II), I910, D. 56I-580.

31 Duschetschkin, A., Biological Absorption of Phosphoric Acid, Jour. Exp. Agr. (Russia), I2, p. 650-666. 
the vanillin decreased with the time, in spite of the fact that the respective solutions became nsore concentrated due to evaporation.

Iiffect of Cumarin on the Groath of Secdlings Grozen in Nutrient Solntion of Various Concentrations.

Tumblers of 250 c.c. capacity were used. They were covered with paraffined paper in which small holes were made with a pointed glass rod. The roots of germinated seedlings were carefully introduced into the tumblers filled with nutrient solution, through the holes of the paper covers, so that the attached seeds remained rested on the upper side of the paper. Four seedlings were planted in each tumbler.

The nutrient solution used was of the following composition:

Calcium nitrate ...................... 2.7 gm. per liter.

Monopotassium phosphate ............... I.5 gm. per liter.

Magnesium sulphate ..................... 0.6 gm. per liter.

Potassium chloride ................... 0.75 gm. per liter.

Ferric sulphate ............................ $0.05 \mathrm{gm}$. per liter.

This nutrient solution was used in full strength and also diluted 3 and to times respectively. The concentrations of cumarin were 200, I00, and ro parts per million. The experiment was run in triplicate. The seedlings were grown for two weeks. The dry weights determined collectively for each set of triplicates are given in Table Io.

TABLE 10.-Dry Weights of Wheat Seedlings Grown for Two Wecks in Different Concentrations of Cumarin.

\begin{tabular}{|c|c|c|c|}
\hline Cumarin. & $\begin{array}{l}\text { Concentration of Nutrient } \\
\text { Solution. }\end{array}$ & Dry Weights. & Relative Weights. \\
\hline p.p.m. & & Grams. & \\
\hline 200 & I : IO & \multicolumn{2}{|c|}{ Killed after 7 days } \\
\hline 100 & I : 10 & & \\
\hline Io & I : IO & 0.2562 & 82 \\
\hline Control & I : IO & .3120 & 100 \\
\hline 200 & I $: 3$ & \multicolumn{2}{|c|}{ Killed after 7 days } \\
\hline 100 & $x: 3$ & & \\
\hline ro & I $: 3$ & .5160 & 76 \\
\hline Control & $I: 3$ & .6820 & I0O \\
\hline 200 & I : I & \multirow{2}{*}{\multicolumn{2}{|c|}{ Killed after 7 “ days }} \\
\hline 100 & $x: I$ & & \\
\hline Io & I : I & .4630 & 60 \\
\hline Control & $I: I$ & .7606 & 100 \\
\hline
\end{tabular}

Is seen from Table ro, the depressing effect of ro parts per million of cumarin is greater in the nutrient solution of the higher concentration. It is evident, however, that the increased nutrient content clinl not increase the deleterious action of the toxin, since the absolute viclus are higher in the higher concentrations of the nutrient solu- 
tion. The deleterions effects of the toxin were more prononited in the case of the higher concentrations of the mutrient solution, frobably lecattice the yields in general were higher with these concentrations.

It is clear, however, that the higher concentrattons of the mutrient did not reduce the toxicity of the cumatrin. The andionating eflect of phosphoric acid on cumarin reported ly Selneiner and Skinner" is evidently not antagonistic in chanater, nor is it cribently lue to the fact that phosplontic acid increases the resisting power of the plant to the action of the toxin, since an increascel concentration of this sulstance did not have the same effect in a balaneed solution.

It is possible that the results obtained by Selneiner and Slinner were due to the resilual effect of the somede of phosphoric actid after the latter was used. It is also possible that the presence of emmarin does not interfere with the alsorplion of phosphoric acid, white it does interfere with the alsorgtion of the other nutrient elentente. and therefore the difference in yieth between the controls and the cumbrin cultures are more pronounced in the catse of distilled water and a balanced nutrient solution than in the case of a solution of phosphoric acid.

\section{Effects of Small Quantitios of Soil on the Biharior of Cumarin and Vanillin.}

The methods nsed were in the matin sinilar to those in the previons experiment. The nutrient solution nsed was the one given above, diluted four times. The experiment was run in triplicate, and contsisted of two series which differed only in the fact that each tmmlilet of the second series received 2 grams of field soil. Both series were run simultaneously, and under exatly the same conditions. The

TABLE II.-Dry Weights of Wheat Secdlings Grown for Two Wecks in WVater Cultures Containing Different Concentrations of Cumarin and Vanillin, with and without the Iddition of Small (O)ontitics of Soil.

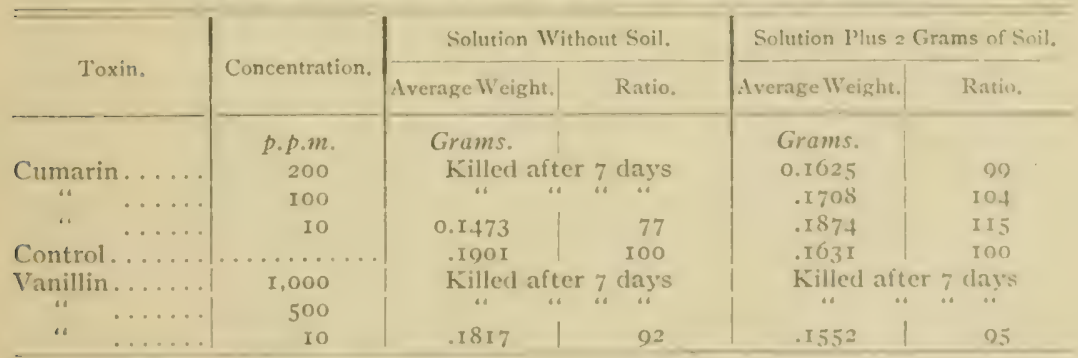

32 Schreiner, Oswald, and Skinner, J. J., Organic Compounds and Fertilizer Action, U. S. Dept. of Agr., Bur. Soils Bul. No. 77. I9I. 
secellings were grown for two weeks. The average weights of the water-free substance from the triplicate cultures are given in Table I I.

As seen from Table II, the toxic effects of the cumarin were completely destroyed by the addition of a very small quantity of soil. As the table shows, the cumarin tumblers of the second, series gave higher yiclds than the controls, but it is safer to ignore this fact since we can not base too much on small differences in yields obtained from scedlings grown for two weeks. It is clear, however, that the toxic effects of the cumarin were entirely overcome. This was also shown by the appearance of the seedlings, especially by the appearance of the roots, which were perfectly healthy and very much branched in the concentration of 200 parts per million of cumarin. The comparison with the similarly treated cultures which had not received any soil is so striking that the ameliorating effect of the soil on the action of cumarin under the conditions of this experiment is beyond any doubt. On the behavior of the seedlings in the vanillin solutions, on the other hand, the addition of soil did not have any effect whatsoever.

The effect produced by the soil in the case of cumarin was probably due not to adsorption, since the quantity of soil was so small, but to decomposition. The difference in the effects of the soil on cumarin and vanillin may be due either to the fact that vanillin is not as readily decomposed by the soil organisms as cumarin, or to the fact that the products of decomposition of vanillin are just as toxic as vanillin itsclf, while the decomposition products of cumarin are not toxic.

This experiment would suggest that the depressing effect of cumarin on the yields in the experiments with soil might be due to different causes than those operative in water cultures.

\section{Experiment with Quartz Cultures.}

The experiment was carried out in half-gallon pots. White quartz. sand thoroughly washed with hydrochloric acid was used. Two kilograns of quartz were used per pot. The nutrient solution given ahove in which enough cumarin and vanillin were dissolved to make 11] the usual respective concentrations. was added to each pot to the extent of 25 percent of the weight of the quartz. The pots were kept at 25 ferecont of moisture, and were watered with distilled water. Nutrient solution was added from time to time. The addition of Here toxins when repeated was in solutions of the respective concentrations and in equivalents of the total moisture. Sixteen wheat seeds were planted in each pot. The germinated seedlings were thinned out to 5 per pot. The experiment was run in duplicate. 


\section{Effects on Germination.}

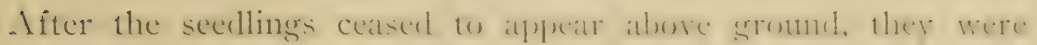
connted, and the perecntage of germination and the relative values. taking the controls as 100 , were calculated. The results are given in Table I2.

TABLE 12.-Effect of Different Concentrations of Cumarin and Vanillin on the Germination of Wheat in Quartz Cultures.

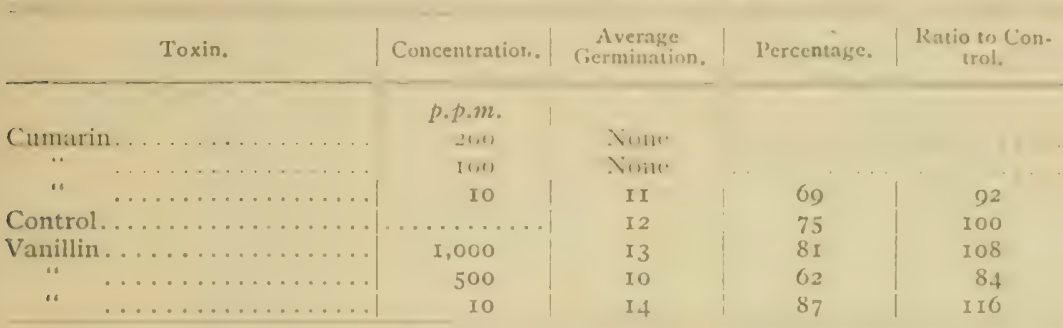

Is seen from Table I2, cumarin hat the same effects on germinattion in cuartz as in a liquid medium. The seeds in the pots of the two highest concentrations, when dug out, had the sinne appeatrance as in the petri dishes - slightly swelled and having marle a very slight effort to germinate.

Vanillin did not have any effect at all on germination in fuartz cultures. The higher restlts than in the control pots ats well ats the lower results obtained in these enltures are to be regarded ats mere fluctuations.

\section{Effect on Groweth.}

- ffter the thinned-out seedlings had been grown for alrout seven weeks, the tops were harvested and the weights of the water-free substance determined. The results are given in Table I3.

TABLE I3.-Dry Weights of Wheat Scedlings Grown in Quartz Cultures Treated with Different Concentrations of Cumarin and Vanillin.

\begin{tabular}{|c|c|c|c|c|}
\hline Toxin. & Concentration. & $\begin{array}{l}\text { Number of } \\
\text { Equivalents } \\
\text { Added. }\end{array}$ & $\begin{array}{l}\text { Average } \\
\text { W'eight. }\end{array}$ & $\begin{array}{l}\text { Ratio to } \\
\text { Control. }\end{array}$ \\
\hline Cumarin ............... & $\begin{array}{c}\text { p.p.m. } \\
200\end{array}$ & I & \multirow{2}{*}{\multicolumn{2}{|c|}{$\begin{array}{l}\text { Did not come up above } \\
\text { quartz } \\
\text { Did not come up above } \\
\text { quartz }\end{array}$}} \\
\hline$\ldots \ldots \ldots \ldots \ldots \ldots$ & 100 & I & & \\
\hline$" \quad \ldots \ldots \ldots \ldots \ldots$ & IO & 2 & I.6 & 194 \\
\hline Control . . . . . . . . & & & 1. . & la... \\
\hline Vanillin............... & $\mathrm{I}, 000$ & 3 & I. 25 & 7.4 \\
\hline " $\quad \ldots \ldots \ldots \ldots \ldots \ldots$ & 500 & 3 & 1.05 & 97 \\
\hline$" \quad \ldots \ldots \ldots \ldots \ldots \ldots$ & ro & 3 & 1.00 & 94 \\
\hline
\end{tabular}


Is seen from Table 13 , the cumarin behaved in quartz cultures in the same way as in water culuures without the addition of soil. The vanillin behaved approximately as in the soil.

\section{General Discussion.}

Since vanillin behaved the same way in quartz sand with a comparatively low adsorptive power as in a clay soil with a comparatively high arlsorptive power, the ameliorating effects of the quartz and of the soil on vanillin were probably not due to adsorption. Since, howerer, the soil organisms added to the water cultures with the small (quantities of soil did not have any effect on the action of vanillin, the ameliorating effect of soil and quartz on this toxin was probably not due to decomposition. In all probability, vanillin is only toxic when applied in a liquid medium which envelops the roots completely in a continuous layer. This would seem to be borne out by the experiment on the effects of cumarin and vanillin on germination in a liquid medium; on longer standing the inhibiting effect of ranillin on gemination decreased, in spite of the fact that the solution became more concentrated, due to evaporation.

The case is entirely different with reference to cumarin. A small quantity of soil added to water cultures containing 200 parts per million of cumarin, which is double the killing concentration, completely destroyed the injurious effects of this toxin. The distribution of the texic solution in films on the surface of the quartz grains did not have any amcliorating effect at all on the action of cumarin. Evidently the ameliorating effect of the soil on this toxin was due to its decomposing power. Adsorption is in all probability excluded, since the small quantities of soil added to the water cultures could not have arlsorthed the comparatively large quantities of the toxin in the higher concentrations. Evidently, the ameliorating effect of the soil on cumarin and vanillin demonstrated in the experiments with soil was due to different causes.

The experiments did not show clearly that the depressing effect of cumarin and vanillin on the yield of the crops grown in soil, which was more pronounced with reference to the yield of grain, was due to the same causes which are operative in water cultures. On the other hand, there are some indications that the effect of the toxins is due to different causes in the soil than in water cultures. The aplearance of the crops in the pots which received the highest concentrations of the toxins was perfectly healthy. No inhibiting effect (in the growth of the roots has been observed. A small quantity of seril adderl to the water cultures which contained cumarin entirely 
destroyed its toxic effects. .ll these considerations- womlel send to stregest that the depression in yedd nherered was not a case oi toxicity, which implies at certain morphological derangenent or certain changes in the compestion and con-titution of the flatut - whstance which juterfere with the nommal physinlegical functions of the plant.

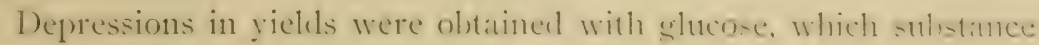
one would hardly consider as a toxin. ${ }^{33}$

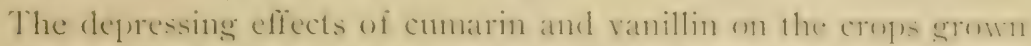
in soil might be due to the genemal effect of suluhle, mom-mutriemt organic matter.

Soluble organic matter may affect the microflora of the soil, stimulating the growth of hamful organisms or the growth wi

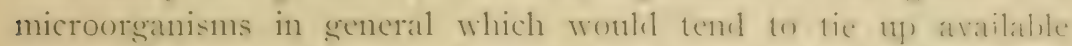
plant food, or inhibiting the growth of useful bacteriat. Thur, ihe results of these experiments would temd to show that the highest concentrations of comarin and vanillin had a depressing oficet on nitrification.

The presence of soluble organic matter may affect to a certain extent the physical conclition of the soil, forming protective illus-on the soil particles and thus interfering with grantulation.

soluble organic matter which is not nsed hy the platut maty interfere, as a forcign sulsstance present in the soil solution. with the absorption by the plant of the necessary elements of plant food.

It might be adeled that these experiments were comblueted moler conditions which entirely excluded drainage, and that the foctuctut watering of the pots tended to compatet the soil very much. lis is possible that ander proper conditions of draninge and cultivation, the results would be different.

On the whole, it might be said that these experinents wombl hatrlly lend much support to the assumption that the presence in the soil of organic substances toxic in water cultures is a fictor of considerable importance nuder field conditions, when the other facturs ai plant growth are normally good.

\section{SUMIMARY.}

T. The evilence offered in favor of the theory of soil toxicity is not'sufficient to establish the fact that the roots of higher plants excrete substances harmful to themselves or to other plants. Vevither is the evidence sufficient to estathlish the presence in the soril of organic substances harmful to plants meler normal field comlitions.

${ }^{33}$ König, Hasenbäumer, und Glenk, 1. c. 
2. The concentrations of 600 parts per million of cumarin and of 3.000 parts per million of vanillin, figured on the basis of the total moisture content of the soil, depressed to some extent the yield of wheat grown to maturity in pots. There are indications, however, that the effect was rather on the soil than on the plant.

3. The addition of small quantities of soil to water cultures entirely destroyed the toxic effects of cumarin, while it did not affect the action of vanillin. It is possible that vanillin is less readily dccomposed by the microorganisms of the soil than cumarin, or that the decomposition products of vanillin are as toxic in water cultures as vanillin itself.

4. In quartz cultures, cumarin has proved to be as toxic as in water cultures, while vanillin behaved approximately the same way as in the soil. Vanillin is evidently toxic only in a liquid medium when it is applied in mass, but not when it is distributed as films over quartz grains or soil particles.

5. The ameliorating effect of phosphoric acid on the action of cumarin reported in Bulletin 77 of the Bureau of Soils would not seem to be due to its antagonistic behavior with reference to that toxin, since it did not behave in the same way in a balanced solution. The ameliorating effects reported might be due either to the residual effects of the base after the phosphate radical was used up, or to the fact that cumarin does not interfere with the absorption by the plant of phosphoric acid while it does interfere with the absorption of the other food elements.

6. The behavior of toxic substances is so different in the soil than in water cultures, that one is hardly justified in drawing conclusions from results obtained with water cultures as to what might take place under actual field conditions.

\section{ACKNOWLEDGMENT.}

The writer is indebted to Dr. T. L. Lyon, under whose direction this work was done, for his kind assistance and valuable suggestions. 


